mas também pela elaboração articulada de um conjunto de conceitos como "jogo da centralidade", "identidade-para-omercado" e "subordinação ativa". Além disto, utiliza-se do que há de melhor na tradição etnográfica ao articular dados etnográficos e estatísticos a processos sociais como a expansão mundial do capital e a construção de narrativas mestras do Estado-nação. Neste sentido, oferece ao leitor uma refinada interpretação dos efeitos locais desses processos, bem como dos sentidos das práticas nativas.

PINO-DÍAZ, Fermín; RIVIALE, Pascal \& VILLARÍAS-ROBLES, Juan J. R. (eds.). 2009. Entre textos e imágenes: representaciones antropológicas de la América indígena. Colección de acá y de allá, Fuentes Etnográficas, n. 5. Madrid: Consejo Superior de Investigaciones Científicas. 274pp.

\section{Barbara Arisi}

Doutoranda PPGAS/UFSC

Estudos sobre representações e imaginários acerca do que os europeus chamaram de "Novo Mundo" e de seus habitantes são apresentados neste livro, que reúne 17 artigos de pesquisadores franceses, espanhóis, mexicanos, peruanos e uma brasileira. São historiadores, arqueólogos e antropólogos, em sua maioria, ligados ao EREA (Équipe de Recherches et d'Enseignement Américaniste), na França, e ao CSCI (Consejo Superior de Investigaciones Científicas), na Espanha.

A coleção mostra como o Novo Mundo alimentou por tantos anos as rodas de debates eruditos nos países colonizadores e como os indígenas foram apresentados na Europa, descritos em textos, desenhados, pintados e, depois, fotografados para su- prir desejos de exotismo e reflexões sobre alteridade, aos poucos transformados em objeto de interesse de pesquisas mais profissionais e que resultaram na criação desse campo amplo de estudos que é o americanismo.

Muitos dos artigos trazem detalhadas informações sobre a política e o debate acadêmico na Espanha, na França, no México e no Peru do século XIX. Além de aprendermos sobre os povos em questão, do lado de cá e de lá do Atlântico, os autores levam-nos a conhecer mais sobre a história das ciências humanas e as disputas por campos e áreas de interesse.

Embora o livro não tenha uma estrita classificação dos artigos que siga uma cronologia das representações dos indígenas americanos, acaba apresentando certa ordem temporal. O texto que abre a coleção é dedicado aos trabalhos de estudiosos criollos mexicanos sobre os achados arqueológicos de duas pedras esculpidas mexica, e o último a fechá-la é dedicado aos personagens literários do escritor norte-americano James Cooper, autor de várias obras cujos principais protagonistas eram índios norte-americanos, entre elas a famosa The last of the Mohicans. Essa novela serviu de base a roteiros e representações indígenas por anos a fio na indústria cinematográfica de Hollywood. Ou seja, avançamos de certo modo dos estudos de representações e interpretações sobre esculturas líticas às imagens registradas em filmes de celuloide.

O livro traz artigos sobre diversos registros históricos do início da colonização e muitas imagens que passaram a ser ícones do Novo Mundo, além de outras tantas menos conhecidas. Ao todo, há 84 ilustrações em preto e branco acompanhando os artigos e, em suplemento nas páginas finais, mais 68 lâminas coloridas impressas em papel brilhante. O acervo imagético é um excelente recurso para quem gosta de preparar apresentações, 
charlas ou aulas ilustradas. A obra é separada em três partes: arquivos/textos, pinturas/desenhos e fotografias/cinema.

A inicial é dedicada aos arquivos e ao trabalho de campo de primeiras fontes especialmente sobre os impérios asteca e inca. Aprendemos sobre diversos autores pioneiros como Rafael Altamira, que tentava disseminar a importância do tratamento científico de fontes documentais sobre a América, e Jiménez de la Espada, naturalista, historiador e animador da "incipiente comunidade científica de americanistas". Ele criou com desenhos seus e de outros artistas um acervo iconográfico que hoje se encontra digitalizado e é de fácil acesso para pesquisadores via internet.

Há uma análise das representações presentes nos próprios trabalhos universitários, cujo corpus são as teses defendidas sobre os Inca na Universidad de San Marcos, em Lima, Peru, entre 1876 e 1925. O autor propõe uma classificação e apresenta as escolas que influenciaram essas teses. Outro artigo aborda personagens proeminentes do debate mexicano no final do século XVIII, estudiosos que tentavam profissionalizar o americanismo a fim de sair da posição de intérpretes de "coleções heterogêneas" feitas por conquistadores a pedido de administradores da Coroa espanhola ou por missionários. Queriam passar a ser, eles próprios, observadores e intérpretes dos dados aos quais tinham acesso em primeira mão.

A segunda parte da obra apresenta artigos que investigam fontes iconográficas dos povos ameríndios. Algumas dessas imagens são muito conhecidas dos pesquisadores brasileiros, como os quadros do pintor holandês Albert Eckhout e do naturalista alemão Von Humboldt; outras nem tanto, como os "Paños" realizados em 1572 ou os desenhos de Poma de Ayala. Os "Paños" retratam eventos da história inca e possivelmente árvores genealógicas deste povo em pinturas feitas por artistas indígenas que, logo após a derrota do Império andino, ainda em 1572, foram enviados pelo vice-rei Francisco de Toledo ao rei Felipe II. Já os desenhos realizados pelo cronista indígena Guaman Poma de Ayala ilustram eventos da história incaica, como as mortes de Túpac Amaro e de Atahualpa, e formam parte de um manuscrito de mais de "mil folios y ochocentos dibujos" despachados ao rei Felipe III como uma espécie de denúncia da selvageria perpetrada pelo mesmo vice-rei Toledo. Ambos os exemplos de arte indígena são em certa medida o que Calavia chama de "mimese de relatos" e exemplo de encontro de historicidades de nativos americanos e espanhóis.

A maioria dos artigos é curta, com cerca de dez páginas. A exceção é o "tal vez demasiado largo", como seu próprio autor admite, sobre De Bry, assinado por Pino-Díaz, um dos editores da coleção. Ele enfatiza a importância dos textos para "captar la diferencia de significado y de vivencia entre las culturas" (:118) e defende que a escrita é essencial para os processos hermenêuticos do discurso etnográfico que não seriam obtidos apenas por meio de imagens. Vale notar a riqueza dos fac-símiles de uma tradução espanhola da obra de Acosta ilustrada por De Bry (originalmente publicada em latim e alemão); o leitor pode tirar suas próprias conclusões sobre o que propõe o artigo em questão.

O único texto em português é assinado por Françoso e aborda as pinturas de Eckhout, incontavelmente reproduzidas e interpretadas, porém a autora apresenta novidades ao centrar a atenção não apenas nas representações de Tapuias e Tupis. Ela nos convoca a observar outros detalhes como a presença aos pés da mulher tapuia de um cachorro, animal 
doméstico trazido pelos portugueses uma das primeiras fontes de curiosidade nativa de povos que estabeleceram contato com o governo brasileiro nos últimos trinta anos. Ou seja, Eckhout aqui estaria lembrando-nos de que "mesmo o mais selvagem - ou tido como o mais selvagem - dos indígenas estava também inserido na sociedade colonial e nela desempenhava um papel relevante" (:135). Podemos então concluir que o pintor dos Países Baixos, nesse sentido, tinha, em pleno ano de 1641, uma visão menos romantizada do que a maioria dos jornalistas e cineastas que ainda hoje se aventuram a produzir documentários nos quais tentam de todos os modos mostrar povos ameríndios como "isolados" ou alheios a qualquer processo histórico.

Conhecemos também nessa coleção de ensaios mais sobre Humboldt e suas teorias acerca da "visão", da estética luminosa dos trópicos e reflexões artístico-científicas sobre conhecer, contemplar e afetar-se pela natureza. Há ainda interpretações de obras de Rugendas. Em um dos artigos seguintes, não se compreende bem o objetivo do autor, pois ele inicia abordando os esboços artísticos de indígenas patagões durante a expedição Malaspina e termina de forma um tanto abrupta sobre os projetos ideológicos da empreitada.

A terceira parte trata da "evolução gráfica". González Reyero faz um passeio pelas imagens como representações científicas que expressam teorias e objetivos específicos de pesquisadores. Leva-nos a refletir sobre as escolhas de imagens em nossos próprios trabalhos acadêmicos, fazendo antropologia visual, porém de um ponto de vista particular especializado na arqueologia. Outros ensaios apresentam conceitos interessantes como "etnografia pitoresca", "estereótipos etnográficos" e "sendero iconográfico", percorridos por certas imagens como o sítio arqueológico de Palenque, que ilustra a capa da presente edição. Infelizmente, o pesquisador ligado à Escola do Museu do Louvre não se dedica a analisar a ilustração "Paso de la Cordillera" (:265) presente nos anexos. Nela, vemos um barbudo de chapéu de palha e botas de cano longo sentado sobre uma cadeira de madeira carregada como uma mochila, presa por uma faixa atada à testa de um índio que sobe de pés descalços uma escada em meio a uma cadeia de montanhas, curvado sob forte temporal e apoiado em um bastão. Certamente, base de um frutífero debate sobre relações entre nativos americanos e pesquisadores europeus.

Outro interessante caminho analítico é percorrido por um professor mexicano que trata de transformações em representações de indígenas yucatecos produzidas por não índios ao longo dos anos de acordo com as relações políticas entre sujeito e objeto de conhecimento. Ele aponta na conclusão que as crescentes autorrepresentações feitas por indígenas merecerão atenção em um "futuro cercano" (:210). Ora, no Brasil, os inúmeros filmes feitos por cineastas kuikuro e kayapó, por exemplo, além do ingresso de tantos colegas antropólogos indígenas nos nossos cursos de pós-graduação, fazem dessa questão algo já presente, nada para o futuro: é aqui e agora que esses estudos existem. Nesses pequenos detalhes, vemos que se trata de uma edição europeia e não latino-americana, o que obviamente não a diminui em nada, apenas revela que o conhecimento é sempre localizado, como nos ensina Donna Haraway.

Chaumeil, autor conhecido de todo amazonista por seus estudos sobre xamanismo, assina o penúltimo texto, dedicado ao médico e viajante francês Crevaux, morto aos 35 anos no Chaco boliviano. Comenta também imagens que "viajaram", como as de Spix \& Martius das 
máscaras rituais tikuna, que reaparecem após nova composição, e coloridas, como ilustrativas de nativos das Ilhas Marquesas, no Pacífico! Ele nos mostra como as imagens adaptam-se (manipuladas, copiadas, cortadas, recompostas) para ilustrar o texto e não o contrário. O trabalho comparativo entre desenhos de uns e fotos de outros - em especial as de Frisch, usadas anonimamente como base para ilustrar trabalhos de Crevaux — foi garimpado em obras muito variadas e é de um detalhamento impressionante, o que apenas confirma a maestria e a dedicação do autor em pesquisar a fundo os tópicos aos quais se dedica.

O último texto é sobre o escritor James Cooper e seus personagens literários "peles-vermelhas", muitos dos quais ganharam vida também nas telas como heróis mitológicos da indústria de Hollywood. O artigo provoca um deslocamento para a América do Norte e é o único a tratar da sétima arte. Hoje, o interesse popular sobre os povos ameríndios segue movido pela fome de exótico e se utiliza de canais como a televisão ou a internet, em documentários e programas "reality show" produzidos por redes como a National Geographic e a BBC, e sites como o YouTube e o Vimeo. Creio que essa é uma das vertentes futuras e atuais de pesquisa para novos americanistas. Para entendermos as raízes dessas representações e aprendermos sobre os estudos pioneiros acerca de nosso continente, a leitura de Entre textos e imágenes certamente será instrutiva. É referência e de grande interesse para historiadores, sociólogos, antropólogos e demais americanistas, mas também para quem é das áreas de museologia, comunicação, design, estudos visuais, estética e história da arte.
PRICE, Richard. 2008. Travels with Tooy: history, memory, and the african american imagination. Chicago: University of Chicago Press. 452 pp.

\section{Thiago de Niemeyer Matheus Loureiro \\ Doutorando - PPGAS - MN - UFRJ}

Há mais de 40 anos pesquisando e escrevendo sobre as populações maroon do Suriname e Guiana Francesa, o antropólogo estadunidense Richard Price vem produzindo algumas das reflexões mais importantes acerca dessas populações, além de ter sido, ao longo do tempo, uma figura de destacada atuação política. Travels with Tooy é uma etnografia produzida a partir de sua experiência com um "obeah man" (espécie de curandeiro ou feiticeiro, muitas vezes temido e respeitado por seu conhecimento das práticas e rituais próprios aos cultos de Obiá caribenhos) saramaka, e são as reflexões desse personagem que animam a escrita do livro. Bastante original do ponto de vista descritivo, o texto é uma rica etnografia baseada, segundo o autor, em sua convivência e na amizade com "um colega intelectual" (:VII).

Protagonista do livro, Tooy é um saramaka "sábio e espirituoso [...], inveterado viajante do tempo" que "adora cruzar fronteiras, entre séculos e continentes, entre o mundo dos vivos e dos mortos, entre o visível e o invisível, entre vilarejos na terra e no fundo do mar" (:X-XI). É preciso destacar a maneira como Price apresenta-o ao leitor. Em sua descrição, Tooy não é um herói, talvez "um tipo de herói grego - um homem carismático que falha de maneiras distintivamente humanas e está, assim, condenado à tragédia mortal", mas nunca herói "na acepção romântica do termo" (:235). É justamente essa forma de descrevê-lo que o torna convincente, acrescentando ao "feiticeiro 